\title{
The Social Problem of Kidnapping and its Implications on the Socio-Economic Development of Nigeria: A Study of Uyo Metropolis
}

\author{
John Domingo Inyang (PhD.)
}

\author{
Department of Sociology and Anthropology \\ University of Uyo, Akwa Ibom State, Nigeria \\ E-mail: drjohninyang@yahoo.com
}

\section{Ubong Evans Abraham}

Department of Sociology and Anthropology University of Uyo, Akwa Ibom State, Nigeria

\author{
Doi:10.5901/mjss.2013.v4n6p531
}

\section{Abstract}

The main thrust of this study was to investigate the problem of kidnapping and its consequences on Nigerians in general and Uyo dwellers in particular. To achieve this objective, the study elicited data through questionnaire from 260 randomly selected respondents comprising of policemen/women from various departments at the state police headquarters, Ikot Akpan Abia, Uyo, in Akwa Ibom State, lawyers from the state judiciary headquarters as well as clergymen and members of the public in the aforementioned study area. Chi-square analytical tool was used to analyze elicited data at 0.05 level of significance. The result from the test of hypothesis one shows that there is a significant relationship between the recurring rates of kidnapping and the people's culture. Test of hypothesis two shows that there is no correlation between kidnapping and the disposition of government. Test of hypothesis three shows that kidnapping is significantly dependent on the provisions of the Nigerian constitution; while result from hypothesis four shows that there is no significant relationship between kidnapping and political activities. Findings from the study shows that, the prevalence of kidnapping in Nigeria is as a result of laxity in the law implementation process to prosecute offenders. Consequent upon this findings it is suggested that the issue of ransom payment by victim's families/relatives to kidnappers should be seriously condemned. Government also should endeavour to create employment for the teaming population of youths as this will assist to check the proliferation of the kidnapping.

Keywords: Kidnapping, social problem, socio-economic development, Uyo metropolis.

\section{Introduction}

Kidnapping has become endemic in the Nigerian society. It is fast becoming a lucrative alternative to armed robbery offence. The gravity of kidnapping is so intense that it has virtually affected most persons in our society. The current dimension of kidnapping became alarmed in the Niger Delta region when militants in February 2006 abducted some oil workers, ostensibly to draw global attention to the dire situation in the oil rich Niger Delta region of the country, the victims were mostly foreigners. Since then the social problem of kidnapping has spread like wild-fire in most parts of the country, especially in the south-eastern region. The targets are no longer foreigners alone; practically every Nigerian is now a target. On the hind sight, however, it is observed that the former Governor of Anambra State was kidnapped in July 10, 2003 by his fellow political party members who were in opposition with him (Emewu \& Anyanwu, 2009). Arguably, therefore, kidnapping is not actually new in the area; but the current lucrative ransom demanding strategy has become a serious social problem for the Government and people of Nigeria.

For instance, in the year 2008 Nigeria was placed sixth on the global kidnap index by an online tourism site. This rating puts the country Nigeria among countries with serious kidnapping problems, behind Philippines, Venezuela, Columbia, Brazil, and Mexico (Ujumadu, 2008; Ekpe, 2009). Such report could serve as an assumption due to lack of accurate statistical data. Also Ekpe, (2009) reported that Nigeria recorded 512 cases of kidnapping and 30 dead persons in kidnappers' den that year as against 353 cases recorded throughout 2008. Similarly, Kyrian 2009 also reported that the former Inspector General of Police in Nigeria had noted that, kidnappers and hostage takers got 15 million in ransom (about 100 million) between 2006 and 2009. Kidnapping cases in southern Nigeria have been ravaging daily 
incidents. The safety of persons in Nigeria and their properties cannot be guaranteed. Kidnapping is an offence punishable by the law in Nigeria. Anybody caught involved in the act is expected to face a penalty of 10years imprisonment. Apart from the above observation some States like Abia, Akwa Ibom, Anambra, Enugu, Imo, Ebonyi, and Rivers have passed into law a bill termed "Prohibition of Hostage Taking and Related Offences Law", with death penalty as punishment for offenders(Inyang, 2009; Ekpe, 2009). Meanwhile, bills with capital punishment against kidnapping are awaiting subsequent readings for implementation by the National Assembly. Unfortunately despite all these stringent laws, no reported case of kidnapping has been successfully prosecuted to serve as deterrent to other potential kidnappers. Nigerians and non Nigerians residing in the country are living in fear as regards who will be the next victim, since kidnappers spare no one as far as their motives are achieved. Over the last few years, the wealthy and the income earners have been picked up by kidnappers who only free their victims after payments of ransom. Old people as well as children between the ages of two and five years have been taken hostage.

The incident of kidnapping has affected Nigeria's image as a nation abroad. It has also affected Nigeria's attempt to develop a viable tourism industry as visitors are regularly warned by their countries to be wary of coming to Nigeria. Many would-be investors have also stayed away for fears of being kidnapped (Ekpe, 2009). Apart from the above observable evidence, many more problems which are associated with the problem of kidnapping will be unraveled during the cause of this research. This study further intends to examine the origin and proliferation of kidnapping in Nigeria. This is necessary because despite measures meant to curb it, kidnapping still prevails and it is on the increase in recent times.

\section{Conceptual Framework}

Asuquo (2009) noted that the term "kidnapping" is difficult to define with precision, because it varies from State to State and jurisdiction to jurisdiction. It is the forcible seizure, taking away and unlawful detention of a person against his/her will. It is a common law offence and the key part is that, it is unwanted act on the part of the victim. It is a restriction of someone else liberty which violates the provision of freedom of movement as enshrined in the constitution of Federal Republic of Nigeria, where every other law takes its cue from. For this reason, Siegel (1986) sees it as a serious offence. Abraham (2010), defined kidnapping as an act of seizing, taking away and keeping a person in custody either by force or fraud. However, it includes snatching and seizing of a person in order to collect a ransom in return or settle some scores of disagreement among people.

Walsh and Adrian (1983) also noted that, kidnapping varies from country to country; therefore the term is uncertain and devoid of any straight jacket definition. That is, it depends on who is defining it and from what perspective and for what purpose. They viewed kidnapping as unlawful seizure and detention of a person's by force against their will. Also, as an act of seizing a person and taking him/her to another country for involuntary servitude or the impressments of males into military or naval service by force or fraud. Furthermore, they cited the view of Robertson (1968), who saw kidnapping as a crime of seizing, confirming abducting or carrying away of persons by force or fraud often subject him or her to involuntary servitude in an attempt to demand a ransom or in furtherance of another crime.

Thomas and Nta (2009) defined kidnapping as robbery of the highest rank. According to them, it is an organized and systematic robbery which is not as deadly as armed-robbery, but more profitable than the former. The profitability has encouraged those that indulged in it to carry on with the act although there is a law prohibiting it. In criminal law, kidnapping is defined as taking away of a person by force, threat or deceit with intent to cause him/her to be detained against his or her will (Asuquo, 2009). Whereas Nwaorah (2009) viewed kidnapping as an act of an angry man who wants to take any person of value hostage, and who could be rescued by loved ones. In most cases, victims are often released after payment of ransom. According, to Ogabido (2009) "kidnapping" means to abduct, capture, carry off, remove or steal away a person(s).

The Chambers $21^{\text {st }}$ Century Dictionary (1996) defined kidnapping as the seizing and holding of someone prisoner illegally, usually demanding for a ransom for his/her release. Dode (2007) saw kidnapping as a process of forcefully abducting a person or group of persons perceived to be the reasons behind the injustice suffered by another group. It is "a low-cost, high-yield terror tactics". This was the initial case in the Niger Delta region of Nigeria.

\section{Causes of Kidnapping}

Many reasons are given as probable causes of kidnapping in Nigeria. Inyang (2009) linked the problem of unemployment as one of such reasons why kidnapping in Nigeria is often associated with youth unemployement. He used the widely 
acknowledged adage, which says that "an idle man is the devil's workshop" to present the situation of unemployment in Nigeria. He noted that there are uncountable able-bodied men and women in Nigeria roaming the streets in search of non existing job. Out of frustration together with mounting responsibilities to tackle many idle young persons have ventured into criminal activities of which kidnapping is not an exemption. Inyang further acknowledged that, a graduate who is unable to secure a job is psychologically bereft of other means of survival. Such situation the young person could develop a negative attitude towards society and attribute his failure to that society. Furthermore, Inyang (2009) also believed that, the proliferation of arms as a result of political patronage of miscreant who were dumped after elections may indirectly encourage and enhanced kidnapping. Inyang likened todays kidnapping situation to the scourge of arm robbery in the early eighties where many young able-bodied men who fought during the Nigerian civil war were discharged and sent home with nothing. Meanwhile since the schools they left behind were destroyed and there were no jobs to engage them and keep them busy. Many of them consequently took to armed robbery, since as ex-soldiers they were armed with weapons, having acquired the skills and guns during the war. The story is almost the same today as politicians employ most idle youths as political thugs and later dumped them after elections. Therefore, the youths (thugs) who have been abandoned by their masters after winning elections are now busy kidnapping innocent persons and relatives of those persons they surged to be wealthy. Similarly, just as the oil boom in the 1970's increased the scale of armed robbery dramatically in the country, the stupendous empowerment of political office holders and their cronies have led many who are far away from these juicy government contracts to turn to kidnapping in order to have their share of the "national cake" as their reward.

The issue of "moral decadence" and the "quest to get rich quick" syndrome have been identified as some of the causative factors of kidnapping. Again Inyang (2009) confirmed these in his proposition that in Nigeria, nobody asks questions on how people make their wealth. According to him, a poor person today can shows up with an expensive car tomorrow and nobody dare to question the sudden wealth. Also, people who have donated money to develop their communities are rewarded with chieftaincy titles thereby creating a wrong impression in the minds of Nigerian youths who thereafter take to kidnapping. The inconsistency between economic transparency and accountability in the running of normal government affairs and the desire to amass wealth among public office holders at different levels of government often also contribute to the leverage by kidnappers. They believe that, when those in government employment loot government treasury openly without fear, they too can as well take the laws into their hands by abducting people for ransom. An argument that easily turns into insignificant when it is considered that businessmen, foreigners and other wealthy people who are very far from government's purse have also fallen victim to this fraudulent acts.

\subsection{Problems with Law Enforcement}

It is often noted that police force personnel lack resources to cope with criminal activities. In addition, corruption within the law enforcement agencies sometimes thwarts serious effort in crime prevention. This was the view of the President of the Philippine Senate, Blas Ople, who observed that $52 \%$ of kidnappings in the Philippines involve active and retired police and military men.

Also, many people today who are desperate in economic and social needs are often the ones who commit kidnappings. So where the gap between the rich and the poor is constantly widening and where the possibilities to earn money in an honest way are often difficult to attain kidnapping turns out be a lucrative means to fall back on and to draw attention to what is considered an intolerable situation. Nwaorah (2009) noted that, in a situation where government officials, especially top ranking persons in civil services who are custodian of government resources spend recklessly or loot, it could automatically encourage few of the dissatisfied persons to vent their anger on them and their relatives. Ogabido (2009:7) agreed that "the issue of poverty and unemployment of youths as well as social injustice and 'unfair distribution of the nations resources are potent causes of kidnapping in Nigeria. These factors have caused the youths to engage in kidnapping and criminal activities as a way of getting their share of nation wealth". He blamed the federal government for lack of equity and fairness in the business of governance as well as lack of responsible leadership that is not complacent or give incentives to people's yearnings and aspirations.

Dode (2007) observed that this harsh reality has placed the Nigerian youth against the Federal Government and the oil producing companies, hence the incessant rate of kidnapping. Citing Ibeanu (1997), Dode further affirmed that the level of political imbalance in the country leads to marginalization and unfair federalism. The conventional wisdom and official position in Nigeria is that such crime like kidnapping arises out of local dissatisfaction over material compensation, paid by oil companies and government for exploitation right and ecological damage. Inyang (2006) noted that his was the 
initial intention of the Niger Delta militants who engaged in abducting expatriate workers of the oil exploring multinational cooperation in Port Harcourt who were operating from a number of rig sites. Throughout history greed has caused many persons to take part in heinous criminal acts. And perhaps kidnapping is one crime that promotes greed and despair on the human person. For many, it is greed that pushes perpetrators to brutalize and torture a stranger and put his family through a cruel ordeal for weeks, months sometimes years.

\subsection{Influence of Hard Drug on Kidnapping}

Okoli (2009) linked the upsurge of kidnapping in Nigeria to high consumption and trafficking on hard drugs. He used Abia State to illustrate the correlation between kidnapping and hard drug consumption and trafficking. According to him, Abia State on the one had is admired for its commerce and flourishing entrepreneurs that have contributed significantly to the economy of the country. On the other hand, Abia State has acquired the notoriety as the highest hard drug consuming and trafficking state, East of the Niger. The barons have ensured the ready availability of drugs not only in Abia State but also in the five neighbouring states of Imo, Akwa Ibom, Rivers, Cross River and Bayelsa. This has led to the upsurge in violent crimes such as kidnapping and armed robbery within the states. Cocaine and heroin have become common drugs of abuse with arrest and seizure recorded in most Local Government Areas of the State. Numerous drugs sale joints are springing up everyday where criminal activities are planned, perfected and executed. He further noted that, some streets in Aba such as York and Park have turned into no-go areas for law abiding residents of Aba metropolis as unscrupulous miscreant have turned them into ghettos and haven for their hard drugs operations. A similar observation was made in Uyo metropolis along Etuk and Nkemba Streets.

\section{Incidence/Prevalence of Kidnapping in Uyo Metropolis}

Since 2003, one social problem that has remained recurrent in the annals of a multi ethnic nation of Nigeria is the incidence of kidnapping. The social malaise has become so pervasive that it has been underscored by the Federal Government as one of the greatest challenges the country is facing (Adebayo, Adeyemi \& Adetayo, 2009). In Akwa Ibom State, particularly in Uyo Capital City, the list of kidnapped persons continues to increase. In December 2008, Owen Owen, an expatriate oil worker with Exxon Mobil was kidnapped in a church premises close to his home and the Mobil quarters in Eket. He was later released a few days after a stipulated ransom had been paid to the kidnappers. Pastors and their children are not spared. On November 24, 2008 one Evangelist Ita Enyong was trailed and kidnapped while on his way to church. The daughter of Abel Damina a prominent preacher in Uyo, was also kidnapped. The list included Mrs. Comfort Aloysius Etok, wife of a serving politician in Akwa Ibom State, who was kidnapped on Thursday, October 16, 2008. This particular incidence compelled the State government to promise an award of $\$ 2,000,000$ to anyone who had information that will lead to the arrest of those kidnappers as well as the release of the politician's wife. Others include; a Lebanese working with STEMCO, Sassive Khali and Hon. Nse Ntuen, the Chairman of ALGON - Association of Local Government Council of Nigeria (David, 2009; Nsoh, 2009). Also one Ikpe of Uruan Local Government Area was kidnapped and up till today, he is no way to be found. Lack of information about him has made people to believe that, he may have been killed by his abductors (Michael, 2009).

In 2009, the incidence/ prevalence of kidnapping in Akwa Ibom State became unbearable. On April 16, 2009, an expatriate worker with Gitto Construction Company was abducted by suspected Niger Delta militants. A construction worker, a Lebanese who was later identified as Mosuf, was abducted at the site of the construction of the Ibom International Airport at Okobo Local Government Area of the State (Kazeem, 2009). Subsequently, in June 14, 2009, the father of the former Speaker, Akwa Ibom State House of Assembly, Chief Nelson Effiong was kidnapped and killed after ransom payment had been made. Mr. Ubong Obot (Obotex) was also reported kidnapped and his barber who came to give him hair cut at his residence was killed in the process. In June 30, 2009; a businessman, Engineer, Emmanuel Okon Ekpeyong and his younger sibling, Mathias, were killed in a foiled kidnapped attempt. According to Inyang (2009), the younger Ekpeyong was shot dead by an unknown gangstar after putting up a brave resistance against the abduction of his brother who was then bundled into the booth of an Audi 80 car. However, the bravado of Engineer Ekpeyong who forced the booth of the car, open and tried to escape while the car was in motion proved to be in vain as he was gunned down by the kidnappers (David, 2009; Inyang, 2009).

Few weeks earlier, in July 2009, two church ministers from different churches in Uyo metropolis were abducted in two separate incidents. Apostle Okuyak Uwah of the New Apostolic Church was whisked away from his home, which was close to the State Police Headquarters at Ikot Akpan Abia. The Apostle was only released later when a stipulated ransom 
was paid to kidnappers who had also shot his son and gateman. Rev. Akan Weeks of Reigners Bible Church also had an experience in the hands of gang men who captured him in Ukanafun Local Government Area on his way to Port Harcourt and he was only set free after five million naira had exchanged hands. Rev. Weeks who recounted his ordeal in a thanksgiving service after his release said the bandits who took him captive displayed a high degree of organization and a large quantity of ammunition at their disposal (Inyang, 2009). A two year old boy, Master Favor Felix Effiong was reported kidnapped by people suspected to be ritualists. According to family sources the boy was kidnapped at about 10pm, on Wednesday, September 23, 2009, on his way from church service with his mother. Also, Deaconess Ema Eshiet, mother of Mrs. Iniobong Eshiet, a former member of the Akwa Ibom State House of Assembly, was reported kidnapped in her house in Etinan Local Government Area of Akwa Ibom State, on Wednesday, November 4, 2009. At the time of documenting this report, it was learnt that those kidnappers did not yet establish contacts with the distraught family members for ransom payments (Effiong, 2009).

On November 25, $2005 \mathrm{Mr}$. Samuel Ita Iniekong, a student of the University of Uyo was kidnapped by unidentified persons. One million naira was demanded for his release (Shield Newspaper, December 9, 2009). Also, on December 4, 2009, the Bank Manager of United Bank of Africa (UBA) was abducted in front of his house along Nelson Mandela road. An undisclosed amount of money was paid for his release according to sources (Akpan, 2009). From the foregoing, it is clear that kidnapping rate is most prevalence in Uyo. Hence, the rationale for the choice of the study area. The undesirable effects of kidnapping on Uyo inhabitants are diverse, and include economic, social, physical, medical, political, international, psychological/emotional, and moral effects (Soyombo, 2009).

\subsection{Economic Effects}

The economic effects of kidnapping include direct and indirect costs. At the individual level, the costs include the economic value of money that may be lost to kidnappers, while the indirect economic cost of kidnapping include expenditures on preventive measures, such as the employment of private security personnel. At the governmental level, the economic effects of kidnapping involve the expenditure on security and security agencies. The federal government budget for 2009 for police formations and command was 195 billion. The Lagos State Government was also reported to have spent three billion naira in two years on security alone (Soyombo, 2009). Much money has been spent on ransom payments. The former Inspector General, Sir. Mike Okipo, disclosed that 15 billion have been paid as ransom to kidnappers between 2006 and 2009 (Kyrian, 2009). The large sum of money spent as ransom payment could affects the State economy drastically, as it could have been use for meaningful economic development.

Also, the nation loses a lot of revenue when expatriates working in the multinational oil companies are attacked. Out of fear, people tend to stay clear from the working environment and the adverse effect is always on the economy. Dode (2007) noted that, in 2006, when kidnappers abducted six foreign expatriates from Shell Oil Company premises the company was forced to closed down and this led to the loss of millions of standard cubic feet per day of gas production for the country.

In Uyo Metropolis, many people are kidnapped often and a lot of money is given out as ransom. This situation affects both the state and household economy. Some people usually went as far as borrowing to bail their relatives out from the hands of hoodlums. In many instances, it is often the bread winners of families that are usually targeted, the implication is always felt particularly within the family, whereby members of such families will have to feed themselves and adjust to their normal daily activities, until they secure the release of the victim. The victims work-place will also be affected adversely. If the victim was a business man or woman, the business will suffer some setback pending his or her return. In a formal organization, the challenges are enormous as the absence of the victim will cause problem within the system, and the output will automatically be affected as well.

\subsection{Social Effects}

Kidnapping affects the social life and social relations of many people who are held hostages in their homes from dusk to dawn, for the fear of being kidnapped. As a result of kidnapping, night travel has become a high risk venture. Furthermore, many people have been forced out of their newly completed houses by kidnappers. People are compelled to present an unfinished look of poverty by not painting the external walls of their houses. Many people are afraid to buy or use new motor vehicles for the fear of kidnappers. It was reported that rich people in Rivers State have resorted to riding in taxi cabs and commercial motorcycles popularly called okada to market, school and social outings as a means to check hostage takers (Soyombo, 2009). 
In regards to inter-personal relationship, kidnapping has also contributed to a relatively high level of mistrust among people. Few people still extend the traditional African hospitality to strangers. Some people do not acknowledge or return greeting by strangers nor oblige strangers asking for direction most people are unwilling to render help to people in distress for fear of being kidnapped. Few people would venture to stop to assist people calling for help on the express way. Increasingly many people nowadays barricade themselves in their homes (Soyombo, 2009).

Most devastatingly, it has been noted that, it is the fear of kidnapping that has contributed to the current high demand for police escort by diverse public officials in the country, thereby further depleting the inadequate police personnel that could have been deployed to street crime control (Soyombo, 2009). In Uyo Metropolis, most people live in fear, as they do not know who will be next to be kidnapped. Some have problem with going out in the night. Commercial motorcyclists have been banned from operation between $6.00 \mathrm{am}-6.30 \mathrm{pm}$ due to the fear of their involvement in kidnapping activities.

\section{Kidnapping and the theory of Structural Functionalism}

The structural functionalism theory is associated with the works of Emile Durkheim (1917), Robert K. Merton (1968) and Talcott Parson (1979). The basic assumption of the theory sees the society as a living organism made up of components part, which functions harmoniously for the survival of the whole system. If any parts fails to contribute to identifiably useful function neither does it promote values consensus among members of the society - it will not be passed on from one generation to the next (Schaefer, 2002).

When applying the theory to explain the social problem of kidnapping in Nigeria, and its implication on the socioeconomic development; structural functionalism assumes that, the economy which is part of the social system is not functioning well. This is due to the mismanagement that occurs within the political sector. This dysfunction within the system causes high level of poverty, unemployment, deprivation as well as marginalization. The result is visualized in the high crime rate of which kidnapping is at the fore front. The crime of kidnapping has been identified as profitable and functional to its perpetrators. The lucrative nature of kidnapping makes it very attractive. Kidnapping as observed in some parts of Nigeria, is identified as a functional measure of politicians to fight their opponents. The money collected as ransoms are means to destabilize the opponents and as well force them to back-out of the political race. In the Niger Delta, kidnapping of foreign expatriates has drawn government attention to look into the plight of the region. This is visualized in the post-amnesty program initiated by Yar'adua/Goodluck administration in 2009, which is expected to restore the much needed peace in the region and the country at large so that socio-economic activities could be conducted without obstruction. However the structural functionalism theory is criticized for not being capable of explaining change and also for addressing the issues of a system as "closed" concept (Charles, Ikoh, lyamba \& Charles, 2005). Despite these criticisms, the theory is justified for its ability to highlight on the functional aspect of crime in our society.

\section{Methodology}

The research design adopted for this study is the survey design. It is chosen on account of the exploratory nature of the study. The design is directed at collecting data using the questionnaire and interview responses. Other secondary data were obtained through research, journals, book and related literature from the library.

There are five major roads network in Uyo metropolis. These are: Ikot Ekpene road; Oron road; Abak road; Aka road; and Nwaniba road. Houses along these roads are either identified with an even or odd number. A systematic random sampling was adopted to select 150 respondents representing members of the general public who were then administered copies of the questionnaires. This method included every second house identified with an even number on the right lane of every road. In each of these roads, 30 eligible respondents who could read and write were given copies of the questionnaires to fill. Where the respondents could not read and write we adopted the interview method based on items on the questionnaire, until the required number of respondents were interviewed.

In the State Judiciary, every office was identified with an even or odd number at the door frame. We also adopted the systematic random sampling to administer copies of the questionnaire to legal advocates. With this method every office identified with an even number at its door frame the questionnaire was administered to every lawyer who occupied those offices. This was done until 50 respondents representing the legal advocates were interviewed. Similarly, using a stratified random sampling method, policemen and women at the state police headquarter, Ikot Akpan Abia, were selected at their various duty posts. In each department, seven men and three women were picked to make-up the 
required 80 respondents for the administration of copies of the questionnaire. Also, list containing the number of churches along the five major roads axis in the metropolis were drawn by the researcher. A systematic random sampling technique was adopted to select most Orthodox and Pentecostal churches that were found within the first-five names on the list. In every first-five names on the list, only one Orthodox Church and that of the Pentecostal denomination was selected until 20 churches were selected. Similarly, clergymen presiding over these selected churches were administered with copies of the questionnaire appropriately. It is worthy to note that, out of the 20 clergymen interviewed, 10 of them were from the Orthodox denomination while the remaining 10 were from the Pentecostal denomination. At the completion of the data collection, all respondents were included in the tables. This helped to show at a glance the trend of the data and the related variables. The Chi-square $\left(\mathrm{X}^{2}\right)$ test of significance with the formula

$$
X^{2}=\sum \frac{(0-e) 2}{e}
$$

was adopted as an analytical tool to determine whether a significant relationship exists between a set of variables or not, where $X^{2}=$ Chi-square sign,

$$
\begin{aligned}
& 0=\text { observed frequency, } \\
& \mathrm{e}=\text { expected frequency, and } \\
& \Sigma=\text { summation sign. }
\end{aligned}
$$

\section{Analysis of Relevant Data}

It should be clearly stated that the researchers prepared and distributed a total of 300 copies of questionnaires, however only 260 copies were retrieved, constituting 87 percent proportion of the sample size (see table 1 for details).

Table 1: Percentage distribution of respondents by data generating procedure

\begin{tabular}{lcccc}
\hline Respondents & $\begin{array}{c}\text { Copies of questionnaire } \\
\text { Administered }\end{array}$ & Percentage & $\begin{array}{c}\text { Questionnaire } \\
\text { Retrieved }\end{array}$ & $\begin{array}{c}\text { Percentage of } \\
\text { whole }\end{array}$ \\
\hline General public & 150 & 50 & 150 & 50 \\
Legal advocates & 50 & 16.6 & 42 & 14 \\
Policemen & 80 & 26.7 & 53 & 17.7 \\
Clergymen & 20 & 6.7 & 15 & 5 \\
Total & 300 & 100 & 260 & 87 \\
\hline
\end{tabular}

Source: Field Work (2010)

\subsection{Hypotheses One}

The first hypothesis of this study was to investigate the relationship between kidnapping and the people's culture

$\mathrm{H}_{\mathrm{I}}$ : There is a significant relationship between kidnapping and the people's culture in Uyo metropolis.

Ho: There is no significant relationship between kidnapping and the people's culture in Uyo metropolis.

Table 2: Respondents perception on kidnapping and its effects on the people's culture

\begin{tabular}{lccccc}
\hline Respondents & \multicolumn{5}{l}{ Responses } \\
& Strongly & Agreed & Disagreed & $\begin{array}{c}\text { Strongly } \\
\text { disagreed }\end{array}$ & Total \\
& agreed & & & $23(22.5)$ & 150 \\
\hline General public & $66(58.3)$ & $32(39.81)$ & $29(29.4)$ & $5(6.3)$ & 42 \\
Legal advocate & $21(16.3)$ & $10(11.15)$ & $6(8.24)$ & $7(7.95)$ & 53 \\
Policemen & $11(20.6)$ & $24(14.1)$ & $11(10.4)$ & $4(2.3)$ & 15 \\
Clergymen & $3(5.8)$ & $3(3.98)$ & $5(2.9)$ & 39 & 260 \\
Total & 101 & 69 & 51 & & \\
\hline
\end{tabular}

Source: Field Work (2010) 
Table 3: Chi-square distribution of respondent's opinion on the relationship between kidnapping and the people's culture

\begin{tabular}{ccccc}
\hline Fo & Fe & Fo $-\mathrm{Fe}$ & $(\mathrm{Fo}-\mathrm{Fe})^{2}$ & $\left(\frac{\mathrm{Fo}-\mathrm{Fe}}{\mathrm{Fe}}\right)^{2}$ \\
\hline 66 & 58.3 & 7.7 & 59.29 & 1.02 \\
21 & 16.3 & 4.7 & 22.09 & 1.36 \\
11 & 20.6 & -9.6 & 92.16 & 4.47 \\
3 & 5.8 & -2.8 & 7.84 & 1.35 \\
32 & 39.81 & -7.81 & 61.00 & 1.53 \\
10 & 11.15 & -1.15 & 1.32 & 0.12 \\
24 & 14.1 & 9.9 & 98.01 & 6.95 \\
3 & 3.98 & -0.98 & 0.96 & 0.24 \\
29 & 29.4 & -0.4 & 0.16 & 0.010 \\
6 & 8.24 & -2.24 & 5.02 & 0.61 \\
11 & 10.4 & 0.6 & 0.36 & 0.03 \\
5 & 2.9 & 2.1 & 4.41 & 1.52 \\
23 & 22.5 & 0.5 & 0.25 & 0.01 \\
5 & 6.3 & -1.3 & 1.69 & 0.27 \\
7 & 7.95 & -0.95 & 0.90 & 0.11 \\
4 & 2.3 & 1.7 & 2.89 & 1.26 \\
Total & & & $\sum X^{2} \mathrm{cal}$. & 20.86 \\
\hline
\end{tabular}

Source: Field Work (2010)

7.1.1 Table Value:

$$
\begin{aligned}
\mathrm{df}= & (\mathrm{NC}-1)(\mathrm{NR}-1) \\
& (4-1)(4-1) \\
& 3 * 3=9 @ \mathrm{D} / \mathrm{F}=0.05 \\
& \mathrm{X}^{2} \text { tab }=16.92 \\
& \mathrm{X}^{2} \text { is significant }
\end{aligned}
$$

\subsubsection{General Decision Rule}

The decision rule for statistical significance states that wherever the calculated chi-square is greater than the table value, the alternate hypothesis should be accepted, while the null hypothesis should be rejected. On the other hand, whenever the table value is greater than the calculated value, the null hypothesis should be accepted, while the alternate hypothesis should be rejected (Spiegel, Schiller \& Srinivasan, 2004).

\subsubsection{Decision}

Since the calculated chi-square is greater than the table value $\left(X^{2}\right.$ cal. $=20.86 \geq X^{2}$ tab. $\left.=16.92\right)$, the alternate hypothesis $\left(\mathrm{H}_{1}\right)$ is accepted while the null hypothesis $\left(\mathrm{H}_{0}\right)$ is rejected. Therefore, the test of hypothesis is indicative that there is a significance relationship between kidnapping and the people's culture.

\subsection{Hypothesis Two}

$\mathrm{H}_{\mathrm{l}}$ : There is a significant relationship between kidnapping and the disposition of government in the state.

$\mathrm{H}_{0}$ : There is no significant relationship between kidnapping and the disposition of government in the state. 
Table 4: Respondents perception on the disposition of government over the issue of kidnapping

\begin{tabular}{cccccc}
\hline Respondents & \multicolumn{5}{c}{ Responses } \\
\hline & Strongly agreed & Agreed & Disagree & Strongly disagree & Total \\
\hline General public & $46(43.3)$ & $52(53.65)$ & $37(39.23$ & $15(13.84)$ & 150 \\
Legal advocate & $14(12.16)$ & $7(15.02)$ & $15(10.98)$ & $6(3.88)$ & 42 \\
Policemen & $13(15.29)$ & $26(18.96)$ & $13(13.86)$ & $1(4.89)$ & 53 \\
Clergymen & $2(4.33)$ & $8(5.37)$ & $3(3.92)$ & $2(1.36)$ & 15 \\
Total & 75 & 93 & 68 & 24 & 260 \\
\hline
\end{tabular}

Source: Field Work (2010)

Table 5: Chi-square distribution of respondent's opinion on the relationship between kidnapping and the disposition of government in the state

\begin{tabular}{ccccc}
\hline Fo & Fe & Fo $-F e$ & $(F 0-F e)^{2}$ & $\left(\begin{array}{cc}(\mathrm{Fo}-\mathrm{Fe})^{2} \\
\mathrm{Fe}\end{array}\right.$ \\
\hline 46 & 43.3 & 2.7 & 7.29 & 0.17 \\
14 & 12.16 & 1.84 & 3.39 & 0.28 \\
13 & 15.29 & -2.29 & 5.24 & 0.34 \\
2 & 4.33 & -2.33 & 5.43 & 1.25 \\
52 & 53.65 & 53.65 & 2.72 & 0.05 \\
7 & 15.02 & -8.02 & 64.32 & 4.28 \\
26 & 18.96 & 7.04 & 49.56 & 2.61 \\
8 & 5.37 & 2.63 & 6.92 & 1.29 \\
37 & 39.23 & -2.23 & 4.97 & 0.13 \\
15 & 10.98 & 4.02 & 1.35 & 0.10 \\
13 & 13.86 & -0.86 & 1.74 & 0.05 \\
3 & 3.92 & -0.92 & .85 & 0.22 \\
15 & 13.84 & 1.16 & 16.16 & 1.47 \\
6 & 3.88 & 2.12 & 4.49 & 1.16 \\
1 & 4.89 & -3.89 & 15.13 & 3.09 \\
2 & 1.36 & 0.62 & .38 & 0.28 \\
Total & & & $\sum X^{2} \mathrm{cal} .=$ & 16.77 \\
\hline
\end{tabular}

Source: Field Work (2010)

\subsubsection{Table Value:}

$$
\begin{gathered}
\mathrm{df}=(\mathrm{NC}-1)(\mathrm{NR}-1) \\
(4-1)(4-1) \\
3 * 3=9 @ \mathrm{D} / \mathrm{F}=0.05 \\
\mathrm{X}^{2} \text { tab. }=16.92 \\
\mathrm{X}^{2} \text { is significant. }
\end{gathered}
$$

\subsubsection{Decision}

Since the calculated Chi-square value is less than the table value $\left(X^{2}\right.$ cal. $=16.77 \leq X^{2}$ tab. $\left.=16.92\right)$, it is concluded from the findings that, the null hypothesis $\left(\mathrm{H}_{0}\right)$ which stated that there is no significant relationship between kidnapping and the disposition of government in the state, is accepted while the alternate hypothesis $\left(\mathrm{H}_{1}\right)$ is rejected.

\subsection{Hypothesis Three}

$\mathrm{H}_{\mathrm{l}}$ : There is a significant relationship between kidnapping and the provisions of the Nigerian constitution.

$\mathrm{H}_{0}$ : There is no significant relationship between kidnapping and the provisions of the Nigerian constitution. 
Table 6: Respondents perception on the strength of the Nigerian constitution to check kidnapping

\begin{tabular}{cccccc}
\hline Respondents & \multicolumn{5}{c}{ Responses } \\
\hline General public & Strongly agreed & Agreed & Disagreed & Strongly disagreed & Total \\
Legal advocate & $46(33.46)$ & $52(40.96)$ & $37(55.38)$ & $15(20.19)$ & 150 \\
Policemen & $6(9.37)$ & $1(11.47)$ & $23(15.51)$ & $12(5.65)$ & 42 \\
Clergymen & $4(11.82)$ & $11(14.47)$ & $30(19.57)$ & $8(7.13)$ & 53 \\
Total & $2(3.35)$ & $7(4.10)$ & $6(5.54)$ & $0(2.02)$ & 15 \\
\hline
\end{tabular}

Source: Field Work (2010)

Table 7: Chi-square distribution of respondents opinion on the relationship between kidnapping and the Nigerian constitution

\begin{tabular}{ccccc}
\hline Fo & Fe & Fo $-\mathrm{Fe}$ & $(\mathrm{Fo}-\mathrm{Fe})^{2}$ & $\frac{(\mathrm{Fo} F)^{2}}{\mathrm{Fe}}$ \\
\hline 46 & 33.46 & 12.54 & 157.25 & 4.70 \\
6 & 9.37 & -3.37 & 11.36 & 1.21 \\
4 & 11.82 & -7.82 & 61.15 & 5.17 \\
2 & 3.35 & -1.35 & 1.82 & 0.54 \\
52 & 40.96 & 11.04 & 121.88 & 2.98 \\
1 & 11.47 & -10.47 & 109.62 & 9.56 \\
11 & 14.47 & -3.47 & 12.04 & 0.83 \\
7 & 4.10 & 2.9 & 8.41 & 2.05 \\
37 & 55.38 & -18.38 & 337.82 & 6.10 \\
23 & 15.51 & 7.49 & 56.10 & 3.62 \\
30 & 19.57 & 10.43 & 108.78 & 5.56 \\
6 & 5.54 & 0.46 & 0.21 & 0.04 \\
15 & 20.19 & -5.19 & 26.94 & 1.33 \\
12 & 5.65 & 6.35 & 40.32 & 7.14 \\
8 & 7.13 & 0.87 & 0.76 & 0.11 \\
0 & 2.02 & -2.02 & 4.08 & 2.02 \\
Total & & & $\sum \mathrm{X}^{2} \mathrm{cal} .=$ & 52.96 \\
\hline
\end{tabular}

Source: Field Work (2010)

\subsubsection{Table Value}

$$
\begin{aligned}
\mathrm{df}= & (\mathrm{NC}-1)(N R-1) \\
& (4-1)(4-1) \\
& 3 * 3=9 @ \mathrm{D} / \mathrm{F}=0.05 \\
& \mathrm{X}^{2} \text { tab. }=16.92, \mathrm{X}^{2} \text { is significant. }
\end{aligned}
$$

\subsubsection{Decision}

From the tested hypothesis three, it is clear that the calculated Chi-square value is greater than the table value $\left(\mathrm{X}^{2}\right.$ cal. $=$ $52.96 \geq X^{2}$ tab. = 16.92), which is an indication that the alternate hypothesis is accepted while the null hypothesis is rejected.

\subsection{Hypothesis Four}

$H_{1}$ : There is a significant relationship between kidnapping and political activities in Uyo metropolis.

$\mathrm{H}_{0}$ : There is no significant relationship between kidnapping and political activities in Uyo metropolis. 
Table 8: Respondents perception on the relationship between kidnapping and politics

\begin{tabular}{llllll}
\hline Respondents & Responses & & & & \\
\hline & Strongly agreed & Agreed & Disagreed & Strongly disagreed & Total \\
\hline General public & $76(77.31)$ & $51(50.77)$ & $9(10.38)$ & $14(11.54)$ & 150 \\
Legal advocate & $24(21.65)$ & $13(14.22)$ & $3(2.91)$ & $2(3.23)$ & 42 \\
Policemen & $23(27.32)$ & $20(17.94)$ & $6(3.67)$ & $4(4.08)$ & 53 \\
Clergymen & $11(7.73)$ & $4(5.08)$ & $0(1.04)$ & $0(1.15)$ & 15 \\
Total & 134 & 88 & 18 & 20 & 260 \\
\hline
\end{tabular}

Source: Field Work (2010)

Table 9: Chi-square distribution of respondents opinion on the relationship between kidnapping and politics

\begin{tabular}{ccccc}
\hline Fo & Fe & Fo $-F e$ & $(F 0-F e)^{2}$ & $\left.\frac{(F 0-F e}{F}\right)^{2}$ \\
\hline 76 & 73.31 & -1.31 & 1.72 & 0.02 \\
24 & 21.65 & 2.35 & 5.52 & 0.25 \\
23 & 27.32 & -4.32 & 18.66 & 0.68 \\
11 & 7.73 & 3.27 & 10.69 & 1.38 \\
51 & 50.77 & 0.23 & 0.05 & 0.001 \\
13 & 14.22 & -1.22 & 1.49 & 0.10 \\
20 & 17.94 & 2.06 & 4.24 & 0.24 \\
4 & 5.08 & -1.08 & 1.17 & 0.23 \\
9 & 10.38 & -1.38 & 1.90 & 0.18 \\
3 & 2.91 & 0.09 & 0.01 & 0.003 \\
6 & 3.67 & 2.33 & 5.43 & 1.48 \\
0 & 1.04 & -1.04 & 1.08 & 1.04 \\
14 & 11.54 & 2.46 & 6.05 & 0.52 \\
2 & 3.23 & -1.23 & 1.51 & 0.47 \\
4 & 4.08 & -0.08 & 0.01 & 0.002 \\
0 & 1.15 & -1.15 & 1.32 & 1.15 \\
Total & & & $\sum X^{2} \mathrm{cal}$. & 7.75 \\
\hline
\end{tabular}

Source: Field Work (2010)

\subsubsection{Table Value}

$$
\begin{gathered}
\mathrm{df}=(\mathrm{NC}-1)(\mathrm{NR}-1) \\
(4-1)(4-1) \\
3 * 3=9 @ \mathrm{D} / \mathrm{F}=0.05 \\
\mathrm{X}^{2} \text { tab. }=16.92 \\
\mathrm{X}^{2} \text { is significant. }
\end{gathered}
$$

\subsubsection{Decision}

Since the calculated Chi-square value is less than the table value $\left(X^{2}\right.$ cal. $=7.75 \leq X^{2}$ tab. $\left.=16.92\right)$, the null hypothesis $\left(\mathrm{H}_{0}\right)$ is accepted while the alternate $\left(\mathrm{H}_{1}\right)$ is rejected.

\section{Discussion}

Findings in the study have revealed that a significant segment of the population have knowledge of the existence of kidnapping in Uyo metropolis and they are able to discuss meaningfully on what they feel are the plausible causes of kidnapping and how it affects them. The analysis derived from respondents in the study shows that $75 \%$ of the respondents agreed that there is kidnapping in Uyo metropolis. A total of $51.5 \%$ respondents strongly attributes 
government failure to meet its basic obligations to its people, as well as greed as the plausible causes of the menace. $33.8 \%$ also agree to the fact, $7.31 \%$ disagree, while the remaining $7.7 \%$ of respondents strongly disagree over the identified causes. It is clear from these results that the rate of kidnapping in Uyo metropolis is alarming and people are aware of it. This situation is responsible for the recent fear over who will be the next victim by the hoodlums. A total of $14.6 \%$ respondents agree that they have been a victim to the hoodlums once. Over $15.8 \%$ of the respondents also agree that either their friend or relation have visited the kidnappers den, only $26.9 \%$ of respondents disagree on the issue, while $36.9 \%$ strongly disagree. Based on this findings, it is implied from the study that if someone is not directly affected by the problem of kidnapping ones friend or relation may be affected. On the reactions of respondents over ransom payment, $8.08 \%$ of the respondents strongly agree of paying ransom before to kidnappers, $13.5 \%$ also agree to have done the same. A total of $29.6 \%$ disagree over the problem while $48.8 \%$ strongly disagree against ransom payment. The implication of these findings is that the result of the test carried-out on hypothesis one which reveals that, there is a significant relationship between kidnapping and the people's culture. People now live in fear and this contributes to the high demand for police escort by various public officials in the country, thereby further depleting the inadequate police personnel that can be deployed to street crime control. The money lost to kidnappers cannot be over emphasized, as both individuals and the government has both spent seriously to counter the menace. This finding is also corroborated by the finding of Soyombo (2009) that the federal government spent 195billion on security alone. While the Lagos state government in the same year pumped-in three billion naira on the same issue.

It was further observed from the study that the Criminal Justice System (C.J.S) made-up of the police, courts and the prisons are ineffective with regards to curbing kidnapping in the country. A total of $26.5 \%$ respondents strongly agree to this fact. Only $18.1 \%$ of the respondents strongly disagree to the fact. These observations shows clearly the inability of the security agencies across the state and Nation to tackle the menace. This situation is noted for numerous security check-points across Uyo metropolis, yet reports on kidnapping activities are still growing daily. It will be recalled that law on death penalty was passed by the Akwa Ibom State Government since 2009. The law stipulated that anyone found guilty of kidnapping offence should be prosecuted. Yet, full implementation of that law has not come to fruition.

In order to find out how Nigerians would react if their relative or friend were to face the full wrath of the law, if convicted of kidnapping. A total of $49.9 \%$ of the respondents strongly agree that they will allow the due process of trial and sentencing to prevail, while $13.1 \%$ disagree over it. To this end, the study also found out that, if government should embark on creating job opportunities to the unemployed youths since they are likely to be the one's capable of perpetrating such acts), it is believed that kidnapping could reduce to a large extent in our society. Also, government should empower the security agencies, by assisting them with sufficed operational facilities to combat crime, while good moral values should be emphasized with zero tolerance to corruption. The study further found out that $81.2 \%$ of the respondents have a strong agreement, $14.6 \%$ for this past while disagrees and $3.46 \%$ have a strong support over the issues suggested.

\section{Conclusion}

The study was undertaken to investigate the problem of kidnapping and its consequences on Nigerians in general and Uyo dwellers in particular. The research was conducted through collaboration with specific objectives, which among them included to examine the effect of kidnapping in the lives of people in Uyo metropolis, identify the role of government in checking the problem of kidnapping, find out the strength of the Nigerian constitution towards the problem of kidnapping, ascertain whether kidnapping in Uyo metropolis has political dimension and proffer useful suggestion as remedies to the problem of kidnapping in Nigeria in general and Uyo in particular based on the study recommendations.

The findings of the study were imperative to conclusions reached on kidnapping in Uyo metropolis. Also there is serious negative implication on the peoples culture, that although government at both the federal and state level have adopted diverse measures to check the menace, yet the problem lies with the laxity on legal implementation over the act. Also, that the proliferation of kidnapping in Uyo metropolis has little to do with political activities, the main motive is economic gain by way of ransom payment of money. Therefore, it is recommended that families and relatives of victims should reject payment of ransom to kidnappers, because ransom payment has been found to be the motivational factor for the criminal activities and operations of the criminals.

\section{Recommendations}

There is need for effective community policing in the country. Not just institutionalizing the machineries, adequate 
operational facilities should be given to the police to assist in their proper functioning. With these observations in mind particularly as it affects people with criminal tendencies.

Henceforth families and relatives of victims should reject payment of ransom to kidnappers, because ransom payment has been noted to act as a motivational factor for the actions/operations of the criminal activities. Effective and well equipped anti-hostage/kidnapping agencies should be set up by the government in order to give stiff resistance to the perpetrators of kidnapping.

Those found to have paid ransom to hostage takers should be warned to refrain from aiding and abetting crime. It is believed that this would go a long way to deter the act of kidnapping in Nigeria.

The joint security forces instituted to check kidnapping should be sustained and given free role to report kidnapper's hideouts. When they are rendered homeless, it will be difficult for them to carry-out their regular criminal operations.

It is also necessary to enforce laws against any political/government official/public office holder found collaborating with kidnappers directly or indirectly. Such a person should be disqualified from holding, contesting/vying for any position in government. This will serve as deterrent to others who may want to venture into such criminal activities.

There is need to encourage the media to organize public programs against the menace. When adequate information is given about the various measures to curb kidnapping, it could serve as threat to the perpetrators and could also assist them to change form their evil ways.

Also, the on-going sim card registration programme by telecommunication operators in Nigeria should be enforced to the later. Subscriber's passport photographs, finger prints, residential /working addresses should be recorded adequately. This will aid the security agencies to check the crime, since kidnapping involves the use of phones for effective perpetration.

It is believed that the implementation of the aforementioned recommendations will certainly curtail kidnapping in Nigeria, which is increasing rapidly in the south-eastern part of the country. The fact that the death penalty which is widely proposed by the affected states of the federation against kidnapping is yet to be implemented suggests laxity in the law implementation process although capital punishment may not be the only way to curb such crime. It also implies that, the would-be criminals who have the intention of adopting the crime as a means of livelihood would do so easily without deterrence. Therefore, it is time for government and relevant agencies to do something about our steaming unemployed youths who are vulnerable to criminality in order to ensure a crime free society susceptible to positive socioeconomic engagement.

\section{References}

Abraham, U. E (2010). The Social Problem of Kidnapping and its Implication on the Socio- economic Development: A Case Study of Uyo Metropolis. A Masters Degree Thesis, Department of Sociology and Anthropology, University of Uyo, Nigeria.

Adebayo, S., Adeyemi, K. and Adetayo, O. (2009). Security: Nigeria, a Nation Still in the Woods at 49. The Punch, October 2, pp. 54 55.

Akpan, E. (2009). UBA Bank Manager Abducted. Vintages Express, December 15, pp. 1 - 2.

Asuquo, M. E. (2009). The Upsurge of Kidnapping and Its Influence on Public Order in Akwa Ibom State. Unpublished Term Paper, Department of Sociology/Anthropology, University of Uyo, Uyo, Akwa Ibom State- Nigeria.

Charles, O. J., Ikoh, U. M., Iyamba, E. I. and Charles, O. A. (2005). Human Development, Child Welfare and Addiction: Social Work Perspective. Ikeja, Lagos: Serenity Printing and Publishing Co. (A Subsidiary of Maxim Consolidation Investment Co.), p. 62.

David, D. (2009). Tackling Security Challenges in Akwa Ibom State. The Sensor, August 4, p. 4.

Dode, R. O. (2007). Incidents of Hostage Taking and the Niger Delta Crisis in Nigeria. South-South Journal of Culture and Development, 9 (1): $162-179$.

Effiong, J. (2009). Gunmen Kidnap former Akwa Ibom Lawmaker's Mum. Sunday Sun, November 8, p. 53.

Emewu, I. and Anyanwu, G. (2009). Anambra kidnap Drama: Forces at Play in Fierce Guber Contest. Daily Sun, October 31, pp. 11 12.

Inyang, J.D. (2006). Development: An Appraisal of Oil Exploration Project and it Environmental Pollution on the Niger Delta Region of Nigeria in the Journal of Global Awareness. St Johns University Queens, New York City USA, Autumn 2006 Vol. 7, No. 4 pp. 5771.

Inyang, U. S. (2009). Kidnapping: Who Can Deliver Nigeria? News D' OR Magazine. Vol. 1(9): July 12, pp. 11-15.

Kazeem, I. (2009). Osufia Regains Freedom after \$1.4Million Ransom... Kidnappers insist on $\$ 100,000$ Balance to Free Vehicle. Sunday Punch, November, 15, p.7.

Kyrian, I. (2009). Intelligence Reports and Kidnapping. Dawn, May 17, p. 9.

Michael, E. (2009). Uran Legislators Lament over Kidnapped Indigene - A Year without Trace ... Weekly Insight, August 6, p .5.

Nsoh, J. A. (2008). Akwa Ibom Raises Task Force on Kidnappers. The Guardian, October 19, pp.1- 4. 
Nwaorah, N. (2009). Are Kidnappers Worst Criminals? Vanguard, March 29, p. 14.

Ogabido, G. O. (2009). Kidnapping: New Brand of Terrorism. Saturday Sun, October 31, p. 7.

Okoli, A. (2008). Revealed! How Traditional Rulers Are Aiding Kidnapping in Abia. Vanguard, July 4, p. 10.

Schaefer, R. (2002). Sociology. Fourth Edition, New York, U. S. A: McGraw-Hill Companies, p. 13.

Siegel, L. J. (2002). Criminology. Second Edition, New York, U.S.A: West Publishing Company, pp. 82-106.

Soyombo, O. (2009). Sociology and Crime Control: That We May Live in Peace. The Guardian, September 17, pp. 56-72.

Spiegel, M. R., Schiller, J. and Srinivivasan, R. A. (2004). Probability and Statistics. Second Edition, New York, U.S.A: Tata McGrawHill, p. 262.

The Chambers 21st Century Dictionary (1996). Edinburgh-England. An Imprint of Larousse Plc, p. 746.

Thomas, T. and Nta, P. (2009). Kidnapped and Persecuted Coman Clem's Wife, a 5 Year Old Girl. Community Pulse, August 10, p. 6. Ughebe, L. and Jimoh, M. (2009). NBA Cautions Governments against Death Penalty for Kidnappers. The Guardian, July 23 , p. 96. Ujumadu, V. (2009). Anambra and High Profile Kidnapping. Vanguard, October 31, p. 45.

Walsh, D. and Adrian, P. (1983). A Dictionary of Criminology. London: Routledge and Kegan Paul Plc, p. 45. 